優れていた. 3 コリメータの違いによる比較ではピクセ ル当りの最大カウントが50～60以上であれば分解能の高 いコリメータの使用により画質が向上するが30以下では 感度の高いコリメータを使用した画像の方が優れていた。 12. RI アンギオによる術前化学㞠法の効果判定

(財)癌研究会附属病院アイソトープ部

○山田康彦・高橋清治・野村悦司

〔目的〕骨腫瘍の原発巣に対する術前化学療法の意義 は局所の病勢を抑え, 患肢保存手術後の再発防止効果が 挙げられる. 早期の効果判定は, 治療効果のある特定薬 剂の選択ができ，より良い治療成績がえられる、そこで 患側の腫瘍性新生血管と健側の血管との血流比を悪化 INDEX としてあらわす.

〔結論〕総合的になされた効果判定が効果有りのとき はINDEX が低く, 効果なしのときは高く変化していっ た.また，骨外形成が少ないものでも判定できる可能性 があり, 術前化学療法の効果判定をする場合週一度の RI アンギオ（HSA）は有用である。

13. オートラシオグラフィのフィルム法と IP 法の比較 検討

東京女子医科大学病院放射線科核医学部

$\bigcirc$ 金谷信一・寺田慎一郎・三本直樹 善田幸治・湯澤 孝・金谷和子

亀卦川孝司・栗原慎一郎

富士写真フィルム株式会社宮台技術開発センター 林 克巳

〔目的〕従来のフィルム法とイメージング・プレート (IP) を用いたオートラジオグラムの感度特性をスタン ダード・ダブレットを試作し比較検討する。

〔結果〕IP 法の線量直線性は非常に良く, $10^{4}$ の広範 囲なダイナミックスレンジを持っていた，核種間感度差

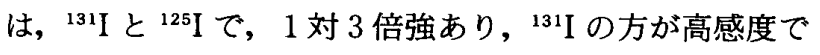
あった。

IP 法とフィルム法の感度差は, 視覚認識限界では約 100倍であった。

\section{4. 乳房保存療法における接線照射法の検討}

\section{慶応義塾大学医学部}

砂岡正良・北川五十雄・五味直人 われわれの施設では乳癌に対して保存療法を施行して いる. 最近ではいくつかの施設から照射法に関する報告 もあり, 乳腺組織にマーキングをして位置決め撮影を行 い, 肺をどの程度ブロックできるかを中心として検討し た.結果は, われわれの方法では乳腺組織に対して $1 \mathrm{~cm}$ 程度照射野が大きく, 必要かつ充分に照射できているこ
とが確認できた。また，リーフコリメータなどによって 肺をブロックした場合ほとんどの症例で乳腺組織を充分 に照射できなくなり不適当であった。

\section{5. 医療法改正後半年の現状と課題}

診療放射線防護研究会

国立東京第二病院 塚田 勝

台東区下谷保健所 大山昇次

新小岩保健相談所 川原広治

済生会栗橋病院 鳥飼孝治

新山手病院 中野静男

結核予防会渋谷䛦療所 村松忠夫

結核予防会結核研究所顧問 川崎幸棺

平成元年10月 7 日に当研究会で行った学習会の内容を 中心に報告した。

主な問題点は, 単位の変更, $\mathrm{H}_{1 \mathrm{~cm}}, \mathrm{H}_{3 \mathrm{~cm}}, \mathrm{H}_{70 \mu \mathrm{m}}$ の導入 不均等被曝測定法および評価となった。課題としては， 診療用放射線照射器具および診療用放射性同位元素の使 用場所制御緩和に伴なう各施設の今後の動向を調查する. 不均等被曝による個人被曝線量の変化を調べる.

今回の改正については他にも多くの疑問や課題がある が，まずは新しい単位を理解し日常業務で支障なく使用 できるようにすることから始める必要がある，安全且つ 経済的な放射線の適正利用ができるマニュアルの作成が 望まれる。

\section{座長集約}

本セッションは, 各演題間に関連性がないため, 1 演 題ごとのまとめとした. 尚, 治療の演題は 1 題だけだっ たため,このセッションでの発表とした。

演題番号 10 岩崎（東芝那須工場）は, 頭部・全身用 SPECT 専用装置 GCA-9300A の開発にあたりその特性 を報告した。本装置の最大の特幑は, ファンビーム コ リメータを用いることにより分解能 $7 \mathrm{~mm}$, 感度 $30 \mathrm{cps} /$ $\mathrm{kbq} / \mathrm{ml} / 1 \mathrm{~cm}$ slice $の$ 高分解能, 高感度な SPECT イメ 一ジを得ることができる.

質問 3 検出器が 4 検出器タイプに比べ, 画質が良い としているが？(国立がん．花井)

答 ファンビーム コリメータを使用しているためで， 平行コリメータと比較した場合, ファンビーム コリメ 一タは 2 倍の感度を持つ. 全体では, 平行コリメータの 1.5倍の感度を持つ.（演者）

演題番号 11 清水ら（慶応大）は, 収集カウントの違 い, ピクセルサイズの違い, コリメータの種類の違い, の 3 通りの収集条件の変化が，画質に与える影響につい て報告した. Max Pixel Count が30カウント以下になる 